\title{
Editorial: Overview and comparison of conservation tillage practices and organic farming in Europe and North America
}

Tillage has been ubiquitous to crop production in most of the world for millennia. Implements used to till the soil that were pulled by animals are known to have existed at least as far back as 8000 BC. $^{1}$ However, growing concerns about the negative consequences of tillage on soil quality ${ }^{2-4}$ spurred widespread interest in reducing tillage practices on farms, particularly in the Great Plains of North America where farming practices brought by immigrants from eastern regions and from Europe were not adapted because of the dry conditions that were encountered. This realization and other developments culminating in the Dust Bowl era during the 1930s made it obvious that innovative farming practices were needed to protect soil from erosion and degradation in quality. A logical consequence is modern no-till farming, where soil is disturbed minimally, if at all, when growing annual cash and forage crops. Advantages of no-till compared with clean or conventional tillage farming have been widely described in the scientific literature, with an excellent recent summary by Triplett and Dick ${ }^{5}$.

Growth in modern no-till farming coincided with the development and commercial use of synthetic herbicides, notably first with 2,4-dichlorophenoxyacetic acid (2,4-D) in the USA $^{6}$, and paraquat in Europe ${ }^{1}$. Herbicides provided farmers with an effective alternative to tillage for controlling weeds but, unlike tillage, did not bury crop residue. The resultant vegetative mulch protected soil from water and wind erosion and, in semi-arid regions, reduced evaporation and improved soil-water storage efficiency $^{7}$. The development of improved herbicides, along with seeding and harvesting equipment designed for use in no-till systems, resulted in the steady growth of this farming method, beginning in the $1990 \mathrm{~s}^{5}$.

Few herbicide options are available to organic farmers, in contrast to conventional farmers, forcing a continued reliance on tillage for weed control in systems managed organically. Research on alternative tillage methods for organic farmers is limited and has lagged behind comparable efforts directed at conventional farmers. Moreover, the so-called bio-herbicides such as natural vinegar, corn gluten and pine extracts that are permitted for use in certified organic farming in some regions of the globe are not, to date, allowed in Europe (European Council (EC) Regulation No. 834/2007 on organic production). Consequences of this dependence on tillage are the negative impacts on soil quality described elsewhere ${ }^{2-4}$.

Arguments have been made about the inferiority of organic farming compared with conventional no-till farming in maintaining or enhancing soil quality ${ }^{8}$, as well as providing other ecosystem services ${ }^{9}$. Curiously, comparisons of conventional no-till farming and tilled organic farming systems failed to reveal distinct soil quality advantages resulting from no-till farming methods. Rather, soil carbon and nitrogen levels were elevated under organic management in one study, presumably in part because of animal manure additions to the organic plots $^{10}$. Potentially mineralizable nitrogen was over $20 \%$ higher in a tilled system transitioning to certified organic production, compared with conventional systems in the first few years of transitioning to long-term no-till management, in a separate study, probably because of the use of a pea green manure crop in the organic system ${ }^{11}$.

There is interest in reducing tillage in organic farming systems for many of the same reasons that tillage has been reduced or eliminated in conventional farming. Peigné et al. ${ }^{12}$ point out that conservation tillage practices, where at least $30 \%$ of the soil surface is covered by a dead vegetative mulch after seeding, could reduce fuel use, enhance soil microbial activity and increase water infiltration rates, as well as reduce soil erosion and leaching of plant nutrients if adopted by organic farmers. The researchers acknowledge the weed control challenges when considering a transition from clean tillage to conservation tillage systems, noting that changes in weed dynamics often deter adoption of conservation tillage by organic farmers in Europe. Likewise, concern over an inability to control weeds when tillage is reduced is a major impediment to adoption of conservation tillage practices among organic farmers in the USA (Duane Boehm, pers. comm.).

Different strategies have been considered for adapting conservation tillage practices to organic farming systems. In North America, most of the present research is directed at reliance on vegetative mulch created by killed cover crops to suppress weeds during a subsequent cash crop phase within a longer crop rotation ${ }^{13}$. This idea is not new and apparently originates from the use of drums with attached blunt blades to kill cover crops in conventional no-till farming systems in Brazil ${ }^{14,15}$. The effectiveness of using a blade roller ${ }^{13}$, also referred to as a rollercrimper $^{16}$, in killing winter rye (Secale cereale L.), winter wheat (Triticum aestivum L.) and black oat (Avena strigosa Schreb.) in the southern USA was reported by Ashford and Reeves almost a decade ago ${ }^{17}$. The two researchers concluded that the three cover crops could be killed effectively if blade rolling was delayed until at least 
the early milk growth stage $(\mathrm{BBCH} \text { growth stage } 73)^{18}$ of kernel development. Subsequent research confirmed this observation for winter rye in the mid-Atlantic region of the USA ${ }^{16}$.

Creamer et al. ${ }^{19}$ compared termination of several cover crop species using a sickle bar mower, flail mower and roller attached to a blade plow in the US Midwest region during the early 1990s. The researchers concluded that while there could be problems with clogging when terminating vine-like cover crops [e.g., hairy vetch (Vicia villosa Roth)], sickle bar mowing was as effective as the roller/blade plow in killing cover crops, and left a thick vegetative mulch that suppressed weeds. Creamer and Dabney ${ }^{20}$ indicated that problems could be encountered when attempting to kill cover crops by rolling, as well as with other mechanical methods that exclude tillage, including several identified by others ${ }^{21}$.

Improvements in blade roller design have occurred since early research was conducted. Newer designs have proven effective in terminating cover crops, and have enhanced the comfort of those operating blade rollers in the field ${ }^{14,15}$. Reports on the ability of cover crop residue to provide near season-long weed control when killed by modern blade rollers exist, and considerable enthusiasm has been generated for 'no-till' organic farming where tillage is eliminated entirely during certain crop phases of a crop rotation ${ }^{22}$. Six papers included in this special issue describe efforts to develop organic conservation tillage practices in North America, and the use of cover crops and blade rollers is a prominent, if not exclusive, focus of the research that is described.

Mirsky et $\mathrm{al}^{23}$ discuss efforts to develop organic conservation tillage systems in the mid-Atlantic region, where much of the recent published research on blade rollers and cover crops in the context of organic no-till has been conducted in North America ${ }^{16,24}$. The authors note that an inability to suppress weeds consistently is a major obstacle that must be overcome for rolled and killed cover crop residue to be considered a viable weed control tool in organic farming systems. Reberg-Horton et al. ${ }^{25}$ indicate that growing conditions in the southeast region of the USA allows for prolific growth by cover crops, sometimes exceeding $9000 \mathrm{~kg} \mathrm{ha}^{-1}$ of dry matter, which results in a thick vegetative mulch capable of suppressing weeds in many cash crops. The southern researchers acknowledge that additional weed control measures sometimes are needed if cover crop mulch alone is relied on for seasonlong weed control.

Delate and $\mathrm{Cwach}^{26}$ in the US Midwest region and Luna et al. ${ }^{27}$ in the US Pacific Northwest region consider the efficacy of rolled and killed cover crop mulch for weed control in tomato (Lycopersicon esculentum Mill.) and several other crops. Delate and $\mathrm{Cwach}^{26}$ report that excellent early-season weed control can be provided by cover crop mulch, but acknowledge that suppression of weeds may be diminished by mid-season. Luna et al. ${ }^{27}$ recognize the potential that organic no-till has in eastern portions of North America, but consider lack of weed control as only one of several problems which prevents this cropping strategy from being adopted in the Pacific Northwest region presently. Carr et al. $^{28}$ report that annual weed growth can be suppressed by rolled and killed cover crops in the semi-arid northern Great Plains region of the USA, but suggest that cover crop mulch will be ineffective in controlling established perennial weed species such as Canada thistle (Cirsium arvense [L.] Scop.). Shirtliffe and Johnson ${ }^{29}$ indicate that weed growth can be greater when cover crops are killed by disking compared with mowing and blade rolling, but acknowledge that refinement is needed before organic no-till is a viable production system on commercial organic farms in western Canada.

A recurring theme from recently completed and ongoing research on organic no-till farming in North America is that efficacy must be improved when relying on killed cover crop mulch for weed control in subsequent crops $^{23-28}$. Interest in organic farming systems which rely on rolled and killed cover crop residue for weed control also has been expressed by European scientists ${ }^{12}$. This is documented, for instance, by a paper presented at the 16th IFOAM Congress in Italy on the direct seeding of fababean (Vicia faba L.) ${ }^{30}$. Although a recent review of the literature failed to identify published results from European field studies on use of killed cover crop mulch for weed suppression ${ }^{12}$, seeding fababean directly into small-grain stubble without pre-plant tillage has been considered by German scientists at the University of Bonn $^{31}$.

Efforts to reduce tillage in organic farming systems by European scientists generally are not focused on its complete elimination, as is the case in North America. Instead, European researchers are working mainly on methods that decrease the amount of inversion tillage being used by organic farmers, particularly when a pasture ley is included in rotations with annual cash crops. This emphasis on reducing, rather than eliminating, tillage completely is exemplified in a series of papers summarizing results from the first 6 years of a long-term field study at the Research Institute of Organic Agriculture located at Frick, Switzerland ${ }^{32-35}$. The experiment, established in 2002, compared two tillage systems across a winter wheat (2002-2003)-sunflower (Helianthus annuus L.; 2004)-spelt (T. spelta L.; 2005)-grass/clover polyculture (2006-2007)-maize (Zea mays L.; 2008) crop sequence between 2002 and 2008: a clean or conventional tillage system where primary tillage was done using a moldboard plow and a reduced tillage system where primary tillage was accomplished using a chisel plow. A stubble cleaner or skim plow was used for removal of the grass-clover ley before maize in both tillage systems, with secondary tillage accomplished using a rotary harrow.

Reduced nitrogen mineralization in spring and elevated weed competition under reduced tillage probably explains the mixed crop yield results between 2002 and 2005, when 
small-grain crop yields were depressed, while oilseed crop yield was elevated slightly ${ }^{32,33}$. Forage yield of the grassclover ley was $25 \%$ higher in reduced tillage plots during 2006-2007 because of improved water retention ${ }^{34}$, and maize silage yields were $34 \%$ higher under reduced tillage in 2008 , despite weed populations that were two to five times higher than in conventional tillage plots ${ }^{34}$. Greater enhancements in soil quality were detected under reduced tillage compared with conventional tillage during the first 6 years of this study and are summarized by Gadermaier et al. ${ }^{35}$ in this special issue.

Colonization of maize roots by arbuscular mycorrhizae across tillage systems was considered by the Swiss researchers in 2005. Interestingly, no enhancement in maize root colonization was detected in reduced tillage compared with conventional tillage plots $^{32}$. Rather, arbuscular mycorrhizal infection of maize roots was slightly higher under conventional tillage. These results contrast with those of others ${ }^{36}$ who found root colonization by arbuscular mycorrhizae to be higher under reduced tillage compared with conventional tillage. $\mathrm{Kabir}^{37}$ concluded in his review of the literature that tillage generally is harmful to arbuscular mycorrhizae and the hyphae networks that are formed. However, the impact of tillage on arbuscular mycorrhizae can be confounded by such things as timing of field activities ${ }^{36,37}$ and the fungal species that are present ${ }^{38}$. This was illustrated even at the intra-specific level of the mycorrhizal fungus Glomus intraradices, where the diversity of mitochondrial large subunit rDNA haplotypes was found to be higher under reduced tillage compared to conventional tillage in the Frick study ${ }^{39}$.

The negative effect that tillage can have on arbuscular mycorrhizal populations and other edaphic factors led some researchers to suggest that adoption of reduced tillage practices fails to capture the soil quality improvements and other benefits that only result when tillage is eliminated completely from farming systems. Grandy et al. ${ }^{40}$ argued that no-till practices must be continuous throughout a crop rotation; many soil quality improvements can be undone in long-term no-till fields by a single tillage operation. Kettler et al. ${ }^{41}$ reported that soil quality declined at shallow soil depths $(0-7.5 \mathrm{~cm})$ following the single use of a moldboard plow in long-term no-till plots, while soil quality improved at a $7.5-15 \mathrm{~cm}$ soil depth, concluding that occasional tillage may result in stratification rather than an overall decline in soil quality. Continuous no-till farming, like that described by Grandy et al. ${ }^{40}$, has not been accomplished successfully when farming organically on a commercial scale ${ }^{42}$. Still, several soil quality and other potential advantages have been attributed to organic no-till farming as it presently is described ${ }^{43}$, and explains the motivation for many of the studies on organic no-till in North America ${ }^{23,25-29}$. European researchers are no less motivated than their North American colleagues in developing viable conservation tillage practices for adoption by organic farmers, but their approach is different and focused on reducing, but not eliminating, tillage when farming organically.

The papers included in this special issue are intended to provide readers with an overview of recently completed and ongoing efforts by North American scientists to develop viable organic no-till systems, and by their European counterparts to develop farming systems that require less tillage when growing organic cash crops. Benefits from adopting reduced tillage and no-till methods for farming organically are identified, as are obstacles that must be overcome before these practices are adopted by large numbers of organic farmers. Multidisciplinary teams of scientists and organic farmers are needed to solve the problems that are encountered when tillage is reduced or eliminated, and organic cash crops are grown. Our hope is that collaborations among those interested in this topic will be spurred as a result of this special issue, including trans-Atlantic efforts between European and North American researchers.

Acknowledgements. The authors sincerely thank Burton Johnson, Herman (Hans) Kandel and Joel Ransom, faculty in the Department of Plant Sciences at North Dakota State University, Fargo, for their helpful comments in preparation of this manuscript.

\section{References}

1 Lal, R., Reicosky, D.C., and Hanson, J.D. 2007. Evolution of the plow over 10,000 years and the rationale for no-till farming. Soil and Tillage Research 93:1-12.

2 Karlen, D.L., Wollenhaupt, N.C., Erbach, D.C., Berry, E. C., Swan, J.B., Eash, N.S., and Jordahl, J.L. 1994. Longterm tillage effects on soil quality. Soil and Tillage Research 32:313-327.

3 Frey, S.D., Elliott, E.T., and Paustian, K. 1999. Bacterial and fungal abundance and biomass in conventional and no-tillage agroecosystems along two climatic gradients. Soil Biology and Biochemistry 31:573-586.

4 Ismail, I., Blevins, R.L., and Frye, W.W. 1994. Long-term no-tillage effects on soil properties and continuous corn yields. Soil Science Society of America Journal 58:193-198.

5 Triplett, G.B. Jr and Dick, W.A. 2008. No-tillage crop production: A revolution in agriculture. Agronomy Journal 100:S-153-S-165.

6 Lyon, D.J., Miller, S.D., and Wicks, G.A. 1996. The future of herbicides in weed control systems of the Great Plains. Journal of Production Agriculture 9:209-215.

7 Peterson, G.A., Schlegel, A.J., Tanaka, D.L., and Jones, O.R. 1996. Precipitation use efficiency as affected by cropping and tillage systems. Journal of Production Agriculture 9:180-186.

8 Trewevas, A. 2004. A critical assessment of organic farmingand-food assertions with particular respect to the UK and the potential environmental benefits of no-till agriculture. Crop Protection 23:757-781.

9 Robertson, G.P., Eldor, A.P., and Harwood, R.R. 2000. Greenhouse gases in intensive agriculture: Contributions of 
individual gases to the radiative forcing of the atmosphere. Science 289:1922-1925.

10 Teasdale, J.R., Coffman, C.B., and Mangum, R.W. 2007. Potential long-term benefits of no-tillage and organic cropping systems for grain production and soil improvement. Agronomy Journal 99:1297-1305.

11 Miller, P.R., Buschena, D.E., Jones, C.A., and Holmes, J.A. 2008. Transition from intensive tillage to no-tillage and organic diversified annual cropping systems. Agronomy Journal 100:591-599.

12 Peigné, J., Ball, B.C., Roger-Estrade, J., and David, C. 2007. Is conservation tillage suitable for organic farming? A review. Soil Use and Management 23:129-144.

13 Vaisman, I., Entz, M.H., Flaten, D.N., and Gulden, R.H. 2011. Blade roller-green manure interactions on nitrogen dynamics, weeds, and organic wheat. Agronomy Journal 103:879-889.

14 Kornecki, T.S., Price, A.J., and Raper, R.L. 2006. Performance of different roller designs for terminating rye cover crop and reducing vibration. Applied Engineering in Agriculture 22:633-641.

15 Kornecki, T.S., Price, A.J., Raper, R.L., and Arrianga, F.J. 2009. New roller crimper concepts for mechanical termination of cover crops. Renewable Agriculture and Food Systems 24:165-175.

16 Mirsky, S.B., Curran, W.S., Mortensen, D.A., Ryan, M.R., and Shumway, D.L. 2009. Control of cereal rye with a roller/ crimper as influenced by cover crop phenology. Agronomy Journal 101:1589-1596.

17 Ashford, D.L. and Reeves, D.W. 2003. Use of a mechanical roller-crimper as an alternative kill method for cover crops. American Journal of Alternative Agriculture 18:37-45.

18 Lancashire, P.D., Bleiholder, H., Van Den Boom, T., Langeluddeke, P.P., Stauss, R., Weber, E., and Witzenberger, A. 1991. A uniform decimal code for growth stages of crops and weeds. Annals of Applied Biology 119:561-601.

19 Creamer, N.G., Plassman, B., Bennett, M.A., Wood, R.K., Stinner, B.R., and Cardina, J. 1995. A method for mechanically killing cover crops to optimize weed suppression. American Journal of Alternative Agriculture 10:157-162.

20 Creamer, N.G. and Dabney, S.M. 2002. Killing cover crops mechanically: Review of recent literature and assessment of new research results. American Journal of Alternative Agriculture 17:32-40.

21 Morse, R.D. 1999. No-till vegetable production - its time is now. HortTechnology 9:373-379.

22 Rodale Institute. 2011. No-Till Revolution. Available at Web site http://rodaleinstitute.org/notill_revolution (accessed June 21, 2011).

23 Mirsky, S.B., Ryan, M.R., Curran, W.S., Teasdale, J.R., Maul, J., Spargo, J.T., Moyer, J., Grantham, A.M., Weber, D., and Way, T.R. 2012. Cover crop-based rotational no-till grain production in the mid-Atlantic region. Renewable Agriculture and Food Systems 27:31-40.

24 Mischler, R., Dulker, S.W., Curran, W.S., and Wilson, D. 2010. Hairy vetch management for no-till organic corn production. Agronomy Journal 102:355-362.

25 Reberg-Horton, S.C., Grossman, J., Kornecki, T.S., Meijer, A.D., Price, A.J., Place, G.T., and Webster, T.M. 2012. Utilizing cover crop mulches to reduce tillage in organic systems in the Southeast. Renewable Agriculture and Food Systems 27:41-48.

26 Delate, K. and Cwach, D. 2012. Organic no-till system effects on organic soybean, corn, and tomato production and economic performance in Iowa. Renewable Agriculture and Food Systems 27:49-59.

27 Luna, J.M., Mitchell, J., and Shrestha, A. 2012. Conservation tillage for organic agriculture: Evolution toward a hybrid system. Renewable Agriculture and Food Systems 27:21-30.

28 Carr, P.M., Anderson, R.L., Lawley, Y.E., Miller, P.R., and Zwinger, S.F. 2012. Organic zero-till in the U.S. northern Great Plains region: Opportunities and obstacles. Renewable Agriculture and Food Systems 27:12-20.

29 Shirtliffe, S.J. and Johnson, E.N. 2012. Progress towards notill organic weed control in western Canada. Renewable Agriculture and Food Systems 27:60-67.

30 Köpke, U. and Schulte, H. 2008. Direct seeding of faba beans in organic farming. Available at Web site: http:// orgprints.org/12379 (accessed November 22, 2011).

31 Massucati, L., Geib, B., and Köpke, U. 2011. Effekte temporärer Direktsaat von Ackerbohnen (Vicia faba sp.) auf die Segetalflora im Ökologischen Landbau (in German). Available at Web site http://orgprints.org/17568/3/ Massucati_17568.pdf (accessed September 13, 2011).

32 Berner, A., Hildermann, I., Fließbach, A., Pfiffner, L., Niggli, U., and Mäder, P. 2008. Crop yield and soil fertility response to reduced tillage under organic management. Soil a Tillage Research 101:89-96.

33 Sans, F.X., Berner, A., Armengot, L., and Mäder, P. 2011. Tillage effects on weed communities in an organic winter wheat-sunflower-spelt cropping sequence. Weed Research 51:413-421.

34 Krauss, M., Berner, A., Burger, D., Wiemken, A., Niggli, U., and Mäder, P. 2010. Reduced tillage in temperate organic farming: Implications for crop management and forage production. Soil Use and Management 26:12-20.

35 Gadermaier, F., Berner, A., Fließbach, A., Friedel, J.K., and Mäder, P. 2012. Impact of reduced tillage on soil organic carbon and nutrient budgets under organic farming. Renewable Agriculture and Food Systems 27:68-80.

36 Kabir, Z., O’Halloran, I.P., Fyles, J.W., and Hamel, C. 1997. Seasonal changes of arbuscular mycorrhizal fungi as affected by tillage practices and fertilization: Hyphal density and mycorrhizal root colonization. Plant and Soil 192:285293.

37 Kabir, Z. 2005. Tillage or no-tillage: Impact on mycorrhizae. Canadian Journal of Plant Science 85:23-29.

38 Jansa, J., Mozafar, A., Anken, T., Ruh, R., Sanders, I.R., and Frossard, E. 2002. Diversity and structure of AMF communities as affected by tillage in a temperate soil. Mycorrhiza 12:225-234.

39 Börstler, B., Thiéry, O., Sykorová, Z., Berner, A., and Redecker, D. 2010. Diversity of mitochondrial large subunit rDNA haplotypes of Glomus intraradices in two agricultural field experiments and two semi-natural grasslands. Molecular Ecology 19:1497-1511.

40 Grandy, A.S., Robertson, G.P., and Thelen, K.D. 2006. Do productivity and environmental trade-offs justify periodically cultivating no-till cropping systems? Agronomy Journal 98:1377-1383. 
41 Kettler, T.A., Lyon, D.J., Doran, J.W., Powers, W.L., and Stroup, W.W. 2000. Soil quality assessment after wheat-control tillage in a no-till wheat-fallow cropping system. Soil Science Society of America Journal 64:339-346.

42 Schonbeck, M. 2010. What is 'organic no-till,' and is it practical? Available at Web site http://www.extension.org/ pages/18526/what-is-organic-no-till-and-is-it-practical/print/ (accessed June 22, 2011).

43 Moyer, J. 2011. Organic No-Till Farming. Advancing No-Till Agriculture - Crops, Soil, Equipment. Acres, USA, Austin, TX.

Patrick M. Carr

North Dakota State University, Dickinson Research Extension Center, 1041 State Avenue, Dickinson, ND 58601, USA

Patrick.Carr.1@ndsu.edu
Paul Mäder

Research Institute of Organic Agriculture, Ackerstrabe, CH-5070, Frick, Switzerland

Nancy G. Creamer Department of Horticultural Science, 224 Kilgore Hall,

Box 7609, North Carolina State University, Raleigh, NC 27695-7609, USA

John S. Beeby Animal Health Diagnostic Center, Molecular Diagnostics Laboratory, Room A3234, Cornell University, Ithaca, NY 14853-6401, USA 